\title{
Editors' Introduction: Literature and the nation: Confronting unhealed wounds
}

\author{
Erol Köroğlu, Zafer Yenal and Deniz Yükseker
}

In the lecture he delivered at the award ceremony for the Nobel Prize in Literature in 2006, Orhan Pamuk said: "For me, to be a writer is to acknowledge the secret wounds that we carry inside us, the wounds so secret that we ourselves are barely aware of them, and to patiently explore them, know them, illuminate them, to own these pains and wounds, and to make them a conscious part of our spirits and our writing." One can discern in his words an implied relationship between wounds of every kind-personal, physical, psychological, social and historical—on the one hand, and literature on the other. Writers often work through and explore the implications and consequences of these wounds not only for themselves or for other individuals, but also for society as a whole. In this context, literature is an act of acknowledgment, recognition and encounter, which in many cases involves confrontation as well. Located between the personal and the social, with their various emotional, sensual and mental manifestations, literature has the potential to break open questions and silences involved in the individual and collective experiences of past and present. This is not only an issue of mediation and reflection. Literature may also unsettle and, thus, serve to rework, historical and social circumstances by way of bringing to light the hidden, the silenced and the repressed, more often than not in a discomforting and disturbing manner.

Erol Köroğlu, Department of Turkish Language and Literature, Boğaziçi University, İstanbul, Turkey, erolkor@gmail.com.

Zafer Yenal, Department of Sociology, Boğaziçi University, Istanbul, Turkey, zyenal@boun.edu.tr. Deniz Yükseker, Department of Sociology, Koç University, istanbul, Turkey, dyukseker@ku.edu.tr.

Authors' Note: While putting together this special issue, E. Köroglu and Z. Yenal were both fellows in the research program entitled "Europe in the Middle East-The Middle East in Europe" of the Wissenschaftskolleg zu Berlin-Institute for Advanced Studies. We are grateful to Wissenschaftskolleg zu Berlin and, particularly, Georges Khalil, the coordinator of this research program, and Christine Hofmann, the program assistant, for making our collaboration possible by providing us with an enriching and stimulating intellectual environment.

1 Orhan Pamuk, My Father's Suitcase: Lecture, Nobel Prize in Literature 2006 (December 7, 2006); available from http://nobelprize.org/nobel_prizes/literature/laureates/2006/pamuk-lecture_en.html. 
This special issue of New Perspectives on Turkey on "Literature and the Nation" aims to look at one of the most debated issues in Turkey, namely the question of national identity and nationalism, through critical perspectives inspired by literature. In recent years, Turkish political and social life has been marked by public debates about how far one can guarantee the freedom of expression and cultural rights for ethnic and religious minorities, and whether past atrocities committed in the name of the nation can be acknowledged. Some of the bitterest discussions have been on the Kurdish issue and the massacre of Armenians in 1915. In the course of these discussions, questions pertaining to national identity and nationalism have come to occupy a central place. The political divide around the issue of Turkish national identity reached its apex after the assassination of Hrant Dink, the outspoken Turkish Armenian journalist, on January 19, 2007. On one level, the murder of Hrant Dink inflicted a fresh wound on the Turkish society's collective memory of 1915. But on another (and equally troubling) level, the omnipresent national identity was used to quickly silence an emerging willingness to "explore, know, illuminate and own our pains and wounds" pertaining to 1915 . There was, thus, a swift change in the public mood, from mourning Dink's murder and raising for the first time the possibility of discussing the past-recall the slogan "We are all Armenians; we are all Hrant" chanted during the funeral procession numbering 100,000 mourners-to a vociferous attempt at preempting that possibility by nationalist political parties and constituencies-recall the slogans along the lines of "We are all Turks, we are all Mehmets" chanted at nationalist demonstrations.

We believe that it is a political urgency-and our intellectual responsibility - to intensify efforts to confront nationalism's symbolic and physical violence which various social groups have experienced in the past and present. Needless to say, knowledge and understanding of the historical specificities of nationalism in Turkey occupy a central place in this endeavor. Looking at the past and the present through literature may help us to understand how the formation of discourses on nationalism and state-building processes have been inscribed in the historical experience and to see in what ways these inscriptions have become fundamental aspects in the constitution of the present.

In undertaking this task, this collection of articles seeks to make a scholarly contribution of a different order as well. The methodological and epistemological divide between literary studies and the social sciences was quite rigid until a few decades ago. As this gap has narrowed gradually, in Turkey as well as elsewhere, a new kind of scholarship has emerged, a scholarship that in examining important historical and socio-political 
issues cuts across previously rigid disciplinary boundaries. Many of the articles in this special issue on "Literature and the Nation" make a genuine effort to come to terms with some of the methodological and conceptual problems of truly melding together social science and literary studies.

The subject of nationalism especially lends itself to a blending of social science and literary studies approaches. Literature, and in particular the novel, has been one of the main vehicles for the consolidation and the popularization of the idea of the nation and national belonging. As such, literature has also played a part in imagining the nation-homogeneously, as was so often the case-hence suppressing voices of difference and dissent. Therefore, the appearance of modern literature and the building and imagining of the nation are almost coterminous processes. In the case of Turkey, a careful analysis of literary works produced in the republican era are illuminating in at least three respects: first, it is possible to find the traces of the aspirations, desires, ideas and ideals instrumental in the shaping of the literary canon that accompanied nation-building and -imagining. Secondly, studying literature may also be fruitful for understanding various dislocations, frustrations, grievances, violence, and disillusionment experienced by different social groups who were subjected to the power of the national state. Thirdly, reading texts with a particular sensitivity to the historical conditions in which they were produced is illuminating, not only for deciphering the traces of a monophonic discourse of nationalism, but also (and more importantly) for delineating its paradoxes and incongruities with the lived experience. Hence, this may also open up a space for coming to terms with the historical contingencies and pluralities that were sought to be silenced and erased in this process.

Addressing the third point mentioned above, the leitmotif of Jale Parla's article in this issue is the incongruity between the representations of Anatolia and the idealized notion of homeland in the nationalist imagination in early republican novels. Underlining the impossibility of capturing the complexities and difficulties of Anatolian reality within the confines of a nationalist literary imagery, Parla argues that early republican novels often spoke about the desire for both saving and conquering Anatolia. At times, this desire was couched in "an internal colonialist attitude toward the motherland to change it." If the treatment of Anatolia follows an allegorical structure in the republican novel, Parla argues, then this national allegory has been progressively undermined in novels published since the 1970s. She meticulously traces how the nationalist representation of the Anatolian topos has been questioned and challenged by novelists such as Yusuf Atılgan, Oğuz Atay and Orhan Pamuk. 
The representation of the nation and the quest for nation-building in Turkish literature was also a gendered process. While the Anatolian land that was to make up the fabric of the nation is represented as female in its simultaneous desirability and elusiveness, the national protagonist is male. However, as Parla underlines, this is a male whose quest to live up to the example of the father (of the nation) was repeatedly frustrated, a subject whose pathos was latent in the early republican novels, and which came to occupy a central place in more recent ones.

Hülya Adak's essay explores the gendered aspect of the representation of the nation by focusing on the autobiographies of women writers in early republican Turkey. While these women were suffragists and/or activists during and following the National Struggle, their autobiographies say little about their private selves. Instead, women's (auto)biographies-from that of the novelist Halide Edib Adıvar to those of Atatürk's adopted daughterswere narratives of the nation, often with a focus on Atatürk at the expense of their personal experiences. Adak observes that these narratives revolve around self-infantilization, the silencing of sexual and romantic desire, and often an erasure of their own roles in the suffragist movement and the National Struggle. In some of these (auto)biographies, the authors' identities as adult women were suppressed underneath the identity of being "daughters" of the Republic and of the "father of the nation." Only since the 1970 s have women's autobiographies in Turkey started to explore the subjectivity of the adult woman/narrator. Hence, Adak says, more recent autobiographical narratives offer us gendered accounts of republican history.

In a similar vein, Engin Kilıç's essay on utopian narratives of the early republican era deals with the uneasy tension between the lived experience and the ideals, ambitions and aspirations of Kemalist nationalists. Kıliç argues that it is not possible to find a genuine critique of the essential aspects of Kemalism in utopian works, which were mostly written by the bureaucratic intellectuals of the 1930s. They largely remained within the confines of the Kemalist imaginary and served to promulgate the idea of Kemalism as an ideal system. Yet, Kılıç's careful reading of these texts reveals the authors' discomfort and disillusionment in the face of practical irregularities and contradictory processes in the implementation of Kemalist ideas, which were often at odds with the imagined ideal social order. Focusing on an unexplored sub-genre of literature in Turkey and locating various approaches to Kemalism within it, Kılıç demonstrates how Kemalism has been a conglomeration of different and sometimes competing political approaches.

Halim Kara in his contribution turns his attention to a broader question, namely about the nature of the relationship between literature and history. 
He examines this issue through a study of the literary portrayals and characterizations of Sultan Mehmed II (1432-1481), the Ottoman conqueror of Istanbul, in historical novels written in different periods in Turkey. He explains how changing depictions of Sultan Mehmed II reflect the dilemmas and the ambivalences inherent in the discursive formation of a new national identity in Turkey in the republican period. Kara's article is important particularly for understanding how the constitutive elements of the nationalist discourse in Turkey-such as the appropriation of the Ottoman past, the role of Islam, the geographical creation of a motherland, and the definition of Turkishness-were constantly negotiated and redefined under the influence of changing social and political conditions. In other words, Kara's study provides us with a vivid exposition of the Janusfaced nature of nationalism.

In fact, the literary output of various writers in the past decade echoes the public debates that revolve around the issue of nationalism on a broader level, either by affirming its monolithic aspects or by offering multi-vocal alternatives to it. On the one hand, a string of best-selling novels in recent years have revisited the National Struggle. Such novels often relay a political message to the contemporary reader: Do not forget our forefathers' sacrifices or diverge from the example set by our national forebears. Whereas early republican novels focusing on the building of the nation implicitly or explicitly deal with the difficulties of that process and the personal troubles of the protagonists, current nationalist novels speak about unquestioned and unquestionable heroism and victory.

Erol Köroğlu examines the relationship between the literary qualities and political message of one of the best examples of this literary wave. In his novel Gâzi Paşa, Attilâ Illhan narrates Mustafa Kemal's leadership in the National Struggle in a style that, according to Köroğlu, is ostensibly based on verisimilitude, but also has epic features. İlhan intertwines history writing and historical fiction in such a way that the reader may easily confuse fact with fiction. His historical novel also exhibits characteristics of a roman à thèse: For instance, Mustafa Kemal is portrayed as the only character with human as well as heroic traits. Other characters in Illhan's narrative appear as shallow representations of various segments of the population, or as antagonists that help Illhan demonstrate his arguments. Köroğlu argues that Gâzi Paşa's authorial intention is to instruct his readers through a narrative of charisma, founded on a specific representation of Mustafa Kemal, in order to propagate a rigid nationalist interpretation of the complex events that occurred during the National Struggle.

On the other hand, as we have suggested above, studying literature may be fruitful for coming to an understanding of the nature of the dislocations 
and violence that certain groups have experienced. Reading such novels may allow the reader to empathize with others in different temporalities. At the same time, these texts may offer possibilities for the future-such as anarchist utopias, or a multi-cultural existence.

A Bakhtinian reading of Murat Uyurkulak's Har, a noteworthy example of contemporary Turkish novel writing, constitutes the backbone of Meltem Gürle's article. She suggests that Har exemplifies what Mikhail Bakhtin calls "carnivalized writing," because it offers the reader a possibility, and even a strong tool, for resisting modernist authority and its worldview in the form of carnival laughter. The novel does this through a systematic use of characteristic inversions, parodies, and crownings and uncrownings of major institutions of modernity (such as the military, mass media and education). Gürle argues that at the heart of Har lies a strong critique of the totalizing effects of Turkey's top-down modernization project; this novel problematizes the notions of progress and rationality by way of giving voice to the silenced and victimized in their different forms of existence. In her words, "Har is a book of bleeding wounds" in which one can see a genuine confrontation with a whole set of social issues and political tensions, including the question of ethnicity and nationality in contemporary Turkey. For Gürle, particularly the chapter entitled "Cinema Grande" can be read as "an anarchist utopia set against the official and totalizing sternness of authority."

In her essay in this issue, Nüket Esen examines two texts by two natives of Diyarbakır, once home to many different ethnic and religious groups. Her reading of the essays of the Kurdish novelist Mehmed Uzun and the short stories of Armenian author Mıgırdiç Margosyan tells about the possibility of feeling for others and thus coming to terms with multiethnicity in Turkey today. In contrast to İlhan's Gâzi Paşa, Margosyan and Uzun's texts do not construct a national memory, but rather collective memories based on reflective nostalgia, and which suggest multiple and polyphonic narratives. As such, these texts may also point to future possibilities for multi-ethnic existence in Turkey.

As the essays in this special issue, through a reading of various literary texts, tackle problems pertaining to the representation of the past and the building of a future, all of them, in a way, address the possibility of acknowledging our wounds. It is because of this common, if implicit, concern woven through the various essays in this special issue, that we dedicate it to the memory of Hrant Dink, who dared to call upon us all to explore and own our wounds-the self-inflicted ones as well as those inflicted by and to others-which have been left unhealed upon his death. 